\title{
The contextualist turn and schematics of institutional fit: Theory and a case study from Southern India
}

\author{
Raul P. Lejano • Savita Shankar
}

Published online: 9 September 2012

(C) The Author(s) 2012. This article is published with open access at Springerlink.com

\begin{abstract}
The policy literature has long recognized the inherent need for a program to fit the unique conditions found in a certain context. We present a theory of institutional contextualism that focuses on the mechanisms by which actors adapt a policy design to fit a situation. We conceptualize institutions as phenomena that are constituted by a constant dialectic between text (the general blueprint) and context (the particular setting). The first half of this dialectic, which is the diffusion of the constitutive text or norm onto the institutional setting, has been discussed in the literature. Our research focuses on the second half, and we delineate, in concept, mechanisms for fitting the program to the local context. We then use a case study of improvised microfinance programs in Tamil Nadu, India, to illustrate how this occurs in reality. The research underscores the unexamined link between effective governance and contextual fit and offers a typology of mechanisms for fit that should inform future research.
\end{abstract}

Keywords Contextualism · Institutional design · Program evaluation · Policy implementation · Policy transfer

\section{Introduction}

In an address to APPAM, ${ }^{1}$ Eugene Bardach underscored the need to understand why policy actors do not simply import a program for implementation but, instead, adapt and customize it for their own uses (Bardach 2004). In the policy design literature, Michael Howlett discusses a related notion of calibration or fine-tuning of policy instruments,

1 Association for Public Policy Analysis and Management.

R. P. Lejano $(\square)$

Department of Policy, Planning, and Design, University of California, SE-I, Room 218G,

Irvine, CA 92697-7075, USA

e-mail: rplejano@yahoo.com

S. Shankar

Asian Institute of Management, Makati City, Philippines

e-mail: shankar.savita@gmail.com 
which invariably takes place if there is to be a congruence between goals and means (Howlett 2009). But, again to cite Bardach, the toolkit of the policy analyst lacks the conceptual framework to make sense of this kind of adaptation (2004). In this article, we focus more closely on delineating and describing the mechanisms behind these processes of adaptation which, we believe, should help us make sense of these processes and understand why they are necessary for a program to thrive.

Our focus on fit responds to another issue identified in recent literature, where there has been a resurgence of critiques of so-called institutional blueprints (Berkes 2007; Ostrom 2008). These blueprints are institutional models that, once conceived, are then applied wholesale to a host of diverse contexts. The problem is that these institutional designs may not exactly match the particular needs of places and communities and, so, not function optimally. For example, Rapley describes how structural adjustment packages, touted by institutions like the International Monetary Fund in the 1980s, were a common recipe which were simply imposed upon a wide range of developing country situations. He notes how it was inevitable that this unitary institutional design should have widely divergent outcomes in different countries (Rapley 1996). Quite simply, these recondite program designs fail to match the complexity and diversity of real-world contexts.

Our response is a return to contextuality. If institutions are to endure, they must somehow fit their context, which begs the question of how to conceptualize "fit". We use the term, institution, to refer to repeated, habitualized patterns of activity in the public sphere, with a specific focus on the delivery of goods and services. Oftentimes, we will use the term, program, as synonymous with institution. This article conducts a systematic analysis of what "making fit" means. This leads to a more explicit description of mechanisms of institutional fit, which is depicted as emerging from an interplay between text (the constitutive blueprint) and context (the specific setting). As will be discussed, extant conceptualizations of fit, such as from contingency theory (Chandler 1962; Lawrence and Lorsch 1967; Pugh 1990; Donaldson 1996, 2001) have not sufficiently described key aspects of fit that are take up herein.

We illustrate this closer focus upon fit by employing these concepts in the case study of microfinance, a policy area characterized by a diversity of local program designs. The attempt is not to be exhaustive but to richly describe the factors and interactions that have contributed to institutional fit in the context of microfinance. This area of application is particularly apt since, in microfinance, the need for fit with local needs and contingencies can be especially pressing. Being typically underfunded and understaffed and employed in widely varying conditions, microfinance programs either fit well into the particular community or soon disappear. The ability to tailor programs to the particular needs of the target community is said to be one of the main factors for success of microfinance programs (Wright 2000; Aghion and Morduch 2005). It has, in fact, become a central tenet in the literature on designing institutions under complexity (e.g., see Lejano 2008). And the means by which programs are so tailored are not exhausted by the material aspects of policy but include cognitive elements like behavioral incentives the way target populations are socially constructed (Schneider and Ingram 1997). Our research agenda aspires to what Mandell and Steelman (2003), writing about organizational networks, described as the need to establish a lingua franca for the study of innovation.

\section{Theory of institutional contextualism: Conceptualizing fit}

Policy scholars had, even in the early literature, already recognized that non-static, process-dependent nature of policy design. As Pressman and Wildavsky wrote: "Fixed 
prescriptions-'knowing that' - give way to 'knowing how'...Implementation is evolution" (1979, p. 176). The literature has decidedly weighed in on the inadequacy of a fixed stage model of the policymaking process (Sabatier 2007). Whether it is referred to as policy redesign (Bobrow and Dryzek 1987; May 1992), transposition (Sewell 1992), or adaptation (Ingram and Schneider 1990), the fact is that implementers exercise some degree of agency in deciding whether to copy an existing policy design or modify it in contextually relevant ways.

This is perhaps most clearly evident in the literature on policy transfer. As Rose stated, purely mimetic copying from one context to another is most often suboptimal and infeasible (2005). Dolowitz and Marsh (2000) posit modes of transfer that involve other than pure copying-i.e., emulation, which is borrowing general ideas but not specific details, and combination, which involves mixtures of different policies. This is similar to Rose's notion of hybridization, which involves evolution of a modified policy design (1991).

We build upon this already established notion of policy/program evolution. To the degree that the policy literature has not focused on it in much detail, this article attempts to more richly describe how policies evolve beyond an initial template, and we identify basic mechanisms involved in this process. We build on a number of concepts found in the policy and organizational literatures (as discussed below), carefully describe mechanisms for policy fit, and illustrate how this focus on fit helps us more deeply understand complex programs like microfinance.

Organizational theorists have described two basic ways that institutional ideas evolve in a place-either by a legitimation-driven process of diffusion from one context to another (Powell and Dimaggio 1991) or by shaping within an existing context (Hannan and Freeman 1977). In truth, these processes occur hand-in-hand, and our work studies how policy designs, imported (or diffused) into a particular context, are then modified and adapted to fit that context. The policy design literature sometimes refers to these processes as calibration (Howlett 2009).

Let us clarify some of the concepts we use, beginning with what we mean by contextualism. In their book, Rediscovering Institutions, March and Olsen (1989, p. 3) described a kind of contextualism that subordinated political institutions to the social structures, like class stratification, found in a place. To them, contextualism referred to institutions being epiphenomenal to context-e.g., bureaucratic processes simply reflecting larger social patterns, such as the presence of a ruling elite. We treat institutions as the primary phenomenon, and for us, contextualism means understanding institutions to be continually constructed through the interaction of the originating blueprint with the sociophysical context. Institutions are not completely determined by context but do exist in a dynamic relationship with it.

Often, theorists mean context to be the organizational field (DiMaggio and Powell 1983), as in a sector of economic activity like finance. In this article, context literally means place and community - the village where a project is conducted, its residents, its streets and alleys, all embedded in a network of relations that make up the institution. We use the term, text, to refer to the formal institutional narrative or blueprint that governs the nature, purpose, and design of a program or policy (Lejano 2006). Our model of institutional fit posits the institution as a phenomenon constituted by the ongoing dialectic between text and context, as depicted in Fig. 1. The institution is assembled by textual and contextual elements (or "constitua") coming together. Semiotically, the meaning of an institution can be understand as the universal ("text") and particular ("context") interacting in hermeneutic fashion. 
Fig. 1 Representation of institutional coherence

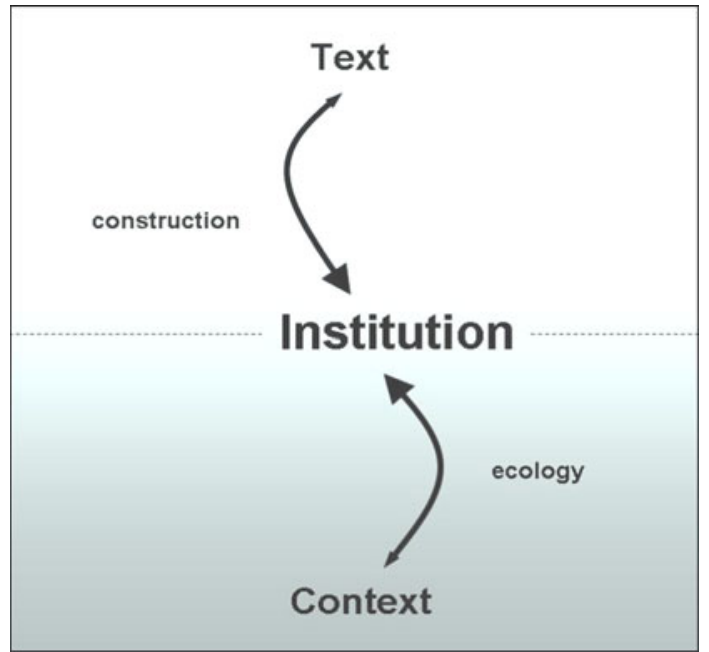

There are two processes depicted in Fig. 1. First, the upper half of the system depicts how institutions are socially constructed by policy actors that can be external to the locale of implementation. We refer to the generic design of the institution as text, and there exists a constitutive relationship between text and institution. The lower half of the system, on the other hand, focuses not on the initial or generic design of the institution but how it then begins to evolve into a better fit with the locale, which we refer to as context. That is, there exists an ecological relationship between institution and context, where 'ecological' simply means that the object of study does not exist autonomously by itself, but in and through relationship with its surroundings. Out of this dialectic between text and context emerges the institution. Figure 1 can be understood as a type of hermeneutic, as defined by Gadamer (1960) and Ricoeur (1991), which is a back-and-forth exchange between text and context, out of which emerges meaning.

Figure 1 is similar in spirit to Richard Scott's notion of top-down and bottom-up organizational processes simultaneously at work (Scott 1995). But his model corresponds to the upper half of Fig. 1, as lower-level actors are both acted on and act upon normative structures above (e.g., governance structures interacting with organizations), emphasizing the agency of policy actors as something active against the structuring nature of norms and standards. But not discussed in his dialectic model of structure and agency is the explicit structuring action of social and physical context (i.e., structuration "from below" these primary agents), on which we focus. In the model herein, the differentiating nature of the local assumes the central role.

Also relevant are what Matland noted as the top-down and bottom-up schools in the implementation literature (Matland 1995; Sabatier 2008). In this case, the effectiveness of an institution is determined either at the level of policy designers (as in Pressman and Wildavsky 1979; Van Meter and Van Horn 1975; Mazmanian and Sabatier 1989) or, locally, at the level of implementation (as in Weatherley and Lipsky 1977; Berman 1980; Hull and Hjern 1987). Our preference is to study these as occurring concurrently-i.e., policy designs may be brought or may diffuse, already complete, to a locale for implementation, but may then be reworked and redesigned at that locale.

We also draw an understanding of contextuality and fit from contingency theory. The central premise, which Lawrence and Lorsche state as "how organizations must vary if 
they are to cope effectively with different environmental circumstances" (Lawrence and Lorsch 1967), underscores the main focus of contingency research, which is making predictable the highly contingent and contextual process of institutional innovation that necessarily occurs. It is understandable, then, that this literature's most important contributions involve delineating general organizational characteristics that respond to characteristics in the organizational environment-e.g., Donaldson's key outcome variables of specialization, formalization, structural differentiation, and decentralization (Donaldson 2001). Our interest, however, is in on a more micro-level, dealing with those particularities introduced at the local level that are not generalizable or comparable on an industry-wide level.

This article will elaborate on the different mechanisms that govern institutional fit. Figure 2 will be used as a schematic guide, the objective being, by the end of the article, to fill in each section of the table with a list of operative mechanisms. The upper half of Fig. 1 is shaded because, as explained below, this aspect is already well covered in the literature and need only be briefly mentioned in this article. Let us now describe and classify the operative mechanisms behind institutional fit.

\section{Upper half: constructive mechanisms}

The upper half of Fig. 1 depicts institutions as socially constructed, externally crafted, and imposed upon a latent field. Construction involves processes of norm diffusion, sharing of routines, and alignment of cognitive and normative frames. These processes, which are well covered in the literature, result in institutional isomorphism (Powell and DiMaggio 1991). Walter Powell and Paul DiMaggio described three mechanisms (coercion, normalization, and mimesis) that mold institutions into pre-determined forms regarded as legitimate in their institutional field. For example, in the world of microfinance, the much acclaimed Grameen bank became the template for microfinance in every corner of the developing world. Quinones Jr. and Seibel (2000) describe how the Grameen model was

Fig. 2 Schematic of institutional mechanisms

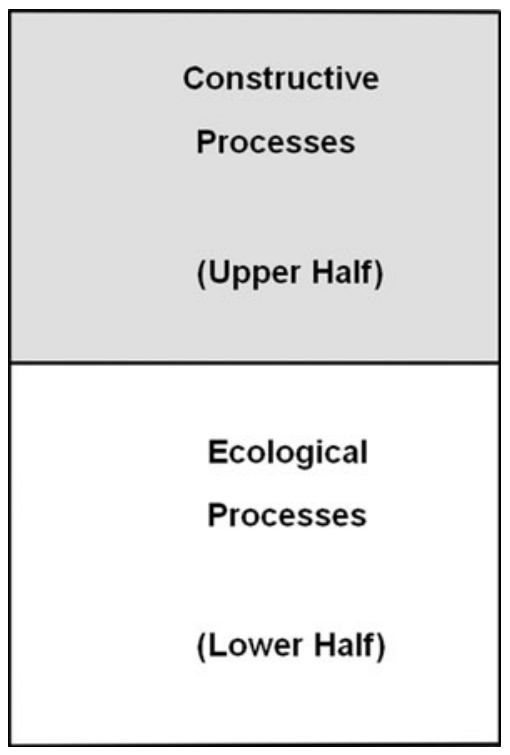


replicated in the Philippines. Mimesis, in the cases they described, involved not just emulating the form of the program but its repertoire of practices (e.g., group loans, pledges). The template or normative frame of a program will be referred to as, simply, "text", reflecting the narrative nature of norm-setting models. The degree to which these narratives transform institutional landscapes is then a function of the efficiency of norm diffusion (Strang and Soul 1998).

This article does not focus much on the upper half of Fig. 1, because these mechanisms have been adequately described by the afore-mentioned and other authors. The concern is, rather, on the lower half, which involves ecological-contextual mechanisms for institutional fit. This also responds to a gap in the literature (as pointed out by Howlett and Rayner 2008) that it is often simply assumed that some policy idea or design is diffused in toto-rather, if one looks closely at "what" is being diffused, one may find that some elements (e.g., policy goals) simply diffuse, while others (e.g., specific policy instruments) undergo translation. As Rose wrote: "In the real world, we would never expect a programme to transfer from one government to another without history, culture and institutions being taken into account" (1991, p. 21) or, in Westley's words "emulation produces innovation" (1987, p. 224). The role of context in determining innovation is clearly an important yet understudied phenomenon. This, we discuss next.

Lower half: ecological mechanisms

In this section, we describe institutions as ecological phenomena and study mechanisms that allow a program to fit into its particular context. In our model, institutions grow out of a place and, to some extent, will exhibit features that belong to it. This ecological effect comes about through at least two processes. First, for an institution to be an institution, it must maintain itself and, for this to happen, institution and environment (i.e., context) must somehow be compatible. Secondly, programs are often carried out under resource-scarce conditions, and there may not be enough budgetary and other resources to build an institution de novo. For this reason, program planners may draw from the resources of a particular place and craft programs based on local opportunities and constraints-let us call this improvisation. For these two reasons-that of coherence and improvisation, one should expect enduring institutions to reflect some characteristics that are unique to their particular context. In this sense, one might expect programs to eventually exhibit polymorphism or differentiation.

Michael Hannan and John Freeman described an ecological model wherein institutions are shaped, formally and materially, by their immediate organizational context (Hannan and Freeman 1977; also Freeman and Audia 2006). In their work, institutions are understood as having evolved into some equilibrium condition with their institutional surroundings. One should find, mirrored in elements or aspects of an institution, determining influences from this context. An example of this phenomenon is Richard Scott's and John Meyer's finding that organizations in more complex, fragmented environments would develop more complex and elaborate administrative structures (Scott and Meyer 1983). This is related to the original notion of imprinting (Stinchcombe 1965) or the reflection of environmental characteristics that helped shaped an institution at its founding.

Unlike isomorphism, mechanisms of fit that produce polymorphism have not been as closely examined in the recent literature. Our research agenda revolves around these mechanisms of fit. It goes beyond the constructionist idea of fit as social legitimacy (Scott 2001), but also beyond the simple ecological notion of homeostasis or equilibrium in a balanced exchange of material across interfaces (Odum 1960). Fit is not only legitimacy, 
which occurs on the symbolic plane, but also depends on the material-i.e., the constant generation and employment of resources. On the other hand, fit is not simply homeostasis, because human institutions exist in a dynamic process of change, conflict, and resolution. They might just as easily exist in a perpetual state of disequilibrium. Institutional coherence is not only a materialist notion, and there is no strictly determinative relationship between environment and institution. Rather, fit is an outcome of multiple processes: material exchange, political action, and influences by the local culture. Concepts from organizational theory are useful in describing mechanisms that make up the lower half of Fig. 1.

\section{Specification and adaptation}

One possible mechanism for fitting a program to the local context together is the phenomenon that Granovetter (1985) termed embedding. That is, the institution is emplaced into a situation as originally constructed. The universal template remains. However, at a further level of explication, the institution takes on particular forms that pertain to their local context. In this case, the embedding relationship between text and context is like translating a universal model into particular form. This mode of fit will be referred to as specification. The other possibility is, while the template remains as designed, elements of the surrounding context adjust to fit to it-let us refer to this mode of fitting as adaptation. The ecological notion of fit as niche is particularly apt. First of all, in ecological terms, the program takes up a physical niche-e.g., its program office takes up space, its workforce takes up labor, its expenditures generate a multiplier effect through the local economy, etc. But perhaps most important is the niche it occupies in the political economy of everyday life among program recipients.

\section{Improvisation}

The program evolves as design refinements are made to adapt it more closely to local conditions-e.g., the microfinance program adds a savings component in response to local needs. Let us refer to this adaptive process as improvisation. In the case of microfinance, the program adapts as it begins to occupy an important place in household and community strategies for survival. This is not simply translation of already existing elements to locally relevant forms, but the addition, removal, or substantial redesign of elements such that a qualitatively new program results. There are refined changes to the original program template, whether by addition, modification, or substitution.

\section{Bricolage}

Another possibility is for text and context to combine in a kind of bricolage (Levi-Strauss 1966; Derrida 1978). Douglas describes bricolage as fragments of pre-existing institutional principles assembled together to form new institutions (Douglas 1986). Here, the work is not that of the engineer engaged in construction but that of the bricoleur engaged in combination. Weick, using jazz as a metaphor, described a similar process within organizations, where policy actors create on the spot, combining elements, routines, and designs at hand in new ways (Weick 1988). Program proponents may combine elements of the institutional design with other various elements and institutional models found in place (e.g., local practices and institutions). What one should find are hybrid program designs, and institutional diversity results from the different ways that program actors improvise 
their institutions. This process of mixing and matching of elements will be referred to as bricolage. Here, parts of different institutional blueprints may be mixed and matched into something altogether unique.

What logics govern the above processes? March and Olsen described the idea of fit as a logic of appropriateness (1989; p. 23). That is, a program or organization is designed such that it conforms to prevailing norms, standards, customs, and styles. As they describe it, the logic of appropriateness most immediately involves similitude, but we extend the idea to include borrowing material and cognitive resources from the context. This can occur as a matter of necessity-e.g., consider programs that are strapped for resources. A good example is that of New Orleans, where some elements of the health system, like Mercy Hospital, were never replaced after Hurricane Katrina. In their stead, some local health professionals took to running health clinics from their own homes (http://www. helpholycross.org/2007/08/nursing-the-low.html accessed October 8, 2009). Let us now turn to the case study to observe ecological fit in everyday institutional life.

\section{Case study analysis}

To illustrate our theory, we examine institutional fit in the area of microfinance, a field characterized by incorporation into countless community settings worldwide and variation in design. Were it not for active processes of fit, microfinance would not have been able to challenge the dominance of traditional financial institutions. The case study examines microfinance institutions in Tamil Nadu, Southern India, a site of almost explosive growth in microfinance institutions (MFIs) and, undoubtedly, a site of great institutional innovation. We trace the growth of MFIs in India using archival information and supplement this with field interviews with microfinance workers and program recipients in Tamil Nadu, India.

We divide the case study analysis into three sections, each studying institutional fit at progressively more refined scales of analysis. At each level, we conduct our analysis by looking for the processes of institutional fit that we outlined earlier.

Section I is a macro-level look at how two main microfinance models, the Microfinance Institution (MFI) Model and the Self-Help Group Bank Linkage Programme (SBLP), evolved in India, and the choices made, at the broad institutional level, about what type of model best served the poor.

Section II is an intermediate or meso-level look at changes in program design, as the models were modified to fit both the specific needs of particular communities and the nature of actors implementing the programs.

Section III is a micro-level look at how households took the various models of microfinance and fitted them, in unique ways, to their individual situations. For this, we use primary data based on field interviews of MFI and SBLP members.

Macro-level fit: institutional choice

On the most general level, the first question that policy actors in India had to answer was: what institutional model for providing financial services might suit the needs of the poor? At this macro-level of analysis, fit mainly involves choosing which models for micro financing to employ in India. We describe below the process of evolution of the microfinance models to understand the context in which these models were initiated. 
The MFI model was a diffusion of the NGO-centered Grameen Bank model from Bangladesh to the Indian context. However, it was not simply diffusion of the model in toto. Rather, the Grameen model underwent processes of specification, as features of it took on local form. The design remained the same, but was simply translated to the local context. The second, parallel solution was the state-initiated SBLP which used the existing infrastructure of state-owned financial institutions to deliver financial services to the poor by using NGOs as boundary agents. Earlier, even though the state-run financial institutions had been specifically mandated to serve low-income groups, it was found that in practice they were not doing so. To address this issue, a model was evolved that would enable these institutions to better reach out to the poor. This is a macro-level type of bricolage, as two distinct programs were combined and allowed to co-exist as local actors saw fit. We discuss these models below.

\section{Translating the Grameen Bank model to the Indian context}

The first model, MFI, is based on the Grameen Bank's group-lending model-a diffusion of an "imported" model into the local scene. Though the main features of the Grameen Bank model are adopted by its replicators the world over, there is a need for translation into the local institutional terms. This is a good example of how the embedding process leads to rich specification. As pointed out by David Gibbons, who was actively associated with Grameen programs in Malaysia and India, Grameen replications in other countries necessarily discover "functional equivalents for essential elements that cannot simply be copied because of cultural, economic or political barriers in the new context. This is the most creative and exciting part of the whole process" (Gibbons 1999). Thus, while the Grameen Bank MFI template remained, local programs necessarily took on local forms that accorded with local practices and institutions-i.e., specification. Good examples of this were found in Cashpor Financial and Technical Services Private Limited (CFTS), one of the earliest Grameen Bank replicators in India and Grama Vidiyal Microfinance Limited (GVMFL), whose field officers we interviewed.

Here are a few concrete examples of this active specification process:

1. In the Bangladesh-based Grameen Bank, initial loan amounts and repayment schemes were based on the activity of paddy husking, with its low capital requirements (around 100 US dollars). In Mirzapur, India, where paddy husking was not done, CFTS found that the closest livelihood generating activity of choice being purchase of a milch animal. And, so, loan amounts of double the original amount were considered.

2. Instead of identifying the poor as those whose total household assets were valued at less than one acre of land, as was done in Bangladesh, CFTS used a housing index to identify the poor. This was because, when CFTS started operating in Mirzapur, India, in 1996, it was viewed with suspicion by the residents, who were hesitant to share information about the land and assets they owned.

3. GVMFL developed the practice of having the borrower's husband, in the case of married borrowers, appear personally at the MFI branch and sign the loan documents along with his wife. The branch manager of the Nanillam Branch of GVMFL highlighted that this practice was particularly useful as a screening mechanism to gauge the level of understanding between the husband and wife, as past experience in his area indicated that households with domestic tensions are likely defaulters.

4. Adjustments are particularly obvious in the written program material. Take, for example, the translation of the Grameen Bank pledge to the Indian context. The 
pledges used by the Grameen Bank and Grama Vidiyal Microfinance Private Limited (GVMFL), an Indian MFI patterned after the Grameen Bank model, are shown in Table 1. This represents a kind of specification that primarily involves translation of the basic norm to local terms. Languages, as found in vehicles like pledges, differ because they emerge from specific groups processes. The sixteen points in the Bangladeshi pledge were formulated based on feedback obtained from Grameen Bank members. When it came time for the Indian MFIs to establish their own routines, they chose to keep their pledges short. The reasoning was that, as pledges are required to be repeated at every meeting, a shorter pledge saves time for borrowers and MFI staff.

5. Translation involves modifying practices to be more compatible with local social norms. In Grameen Bank, Bangladesh, MFI members are required to salute the Grameen Bank field officer at the meeting. This symbolic gesture is used to emphasize the discipline required from the MFI borrower. This practice was not adopted by MFIs in India, however, as it would likely have been viewed as undemocratic in that country's political culture (Harper 2002).

\section{SBLP: combining existing institutional models}

Policy actors also chose a second model, the SBLP (Self-Help Group Bank Linkage Program), which evolved as a parallel institution, distinct from the MFI. The creation of this model is itself an example of bricolage as it involved bringing together different institutions, each able to provide only one part of the solution. India's state-owned banks had branches in rural areas but were still inaccessible to low-income groups. This is due to their insistence that customers visit their branches at specific hours of the day. Drawing on field experiments conducted by Asia Pacific Rural and Agricultural Association (APRACA) and International Labour Organization (ILO), NABARD (the National Bank for Agriculture and Rural Development) decided to involve non-governmental organizations (NGOs) to bring together the formal banking structure and the rural poor. We see therefore that both the MFI model and the SBLP are examples of how sharing of institutional models across countries has played an important role in developing microfinance in India. These NGOs were already involved in various initiatives involving community mobilization and training and, so, were well-placed to lead a community-based banking initiative. NABARD designed training programs for low-income women on saving and managing loans. The goal was to build these groups' capacity to access bank funds, eventually managing their own finances without NGO help (NABARD 1991). This women-centered, self-help model was subsequently replicated throughout the country.

Bricolage is the process by which institutions are pieced together to fit the needs of a situation. While SBLP tended to concentrate in those low-income neighborhoods where bank branches were already located, private sector MFIs tended to fill in the spatial gaps, earlier on. However, as the years passed, the great demand for microfinance led to MFIs and SBLPs spilling over into common areas. MFIs and SBLPs started serving small areas within a town, each holding meetings wherever there were enough interested low-income women who lived within walking distance. For example, as recounted to us by the branch manager of the GVMFL MFI program in Tiruvarur district in Tamil Nadu, their branch begun doing business in January 2009 and, by July 2009, had 1,350 borrowers. Bank centers were established wherever there was a group of twenty potential members who lived on the same or adjacent street. GVMFL's improvised rule that members come from no farther than the next street was related to their desire to maintain regular attendance at the weekly meetings. 
Table 1 Pledges of Grameen Bank and Grama Vidiyal Microfinance Private Limited

\begin{tabular}{ll}
\hline Grameen Bank (Bangladesh) & $\begin{array}{l}\text { Grama Vidivalmkro Finance Private Limited } \\
\text { (India) }\end{array}$
\end{tabular}

1. We shall follow and advance the four principles of Grameen Bark: Discipline, Unity, Courage, and Hard Work - in all walks of our lives

2. Prosperity we shall bring to our families

3. We shall not live in dilapidated houses. We shall repair our houses and work toward constructing new houses at the earliest

4. We shall grow vegetables all the year round. We shall eat plenty of them and sell the surplus

5. We shall plant as many seedlings as possible

6. We shall plan to keep our families small. We shall minimize our expenditures. We shall look after our health

7. We shall educate our children and ensure that they can earn enough to pay for their education

8. We shall always keep our children and the environment clean

9. We shall build and use pit latrines

10. We shall drink water from tube wells. If it is not available we shall boil water or use alum

11. We shall not take dowry at our son's weddings. Neither shall we give any dowry at our daughter's wedding. We shall keep our center free from the curse of dowry. We shall not practice child marriage

12. We shall not inflict any injustice on any one, neither shall we allow anyone to do so

13. We shall collectively undertake bigger investments for higher incomes

14. We shall always be ready to help each other. If any one is in difficulty, we shall all help him or her

15. If we come to know of any breech of discipline in any center we shall all go there and help restore discipline

I6. We shall take part in all social activities collectively
1. Grama Vidiyal is our organization. We will strive constantly to grow our organization

2 We will lead our organization by acting as the owners, managers and workers

3. We will deposit our savings and repay our loans every week without fail

4. We will utilize our loans in a proper manner

5. We will strive to increase our income and progress our family

6. We will co operate with group members and organization members

7. We will implement social improvement schemes in a proper manner

8. Thriftiness protects the family, savings protects the nation

9. To get a loan is a human right. To repay it without fail is our duty

Source: Grameen Bank pledge from www.grameen.com and GVMFL pledge, transcribed, and translated into English by one of the co-authors during field visit

At a macro-scale of analysis, the MFI and SBLP models soon had overlapping jurisdictions. We expected to see a fair amount of competition between the two models in Tamil Nadu. Surprisingly, the GVMFL field officers we interviewed did not consider the SBLP to be a competitor. They mentioned that most women decided to also join the SBLP in order to participate in community actions and avail of Government benefits and subsidies. At times, there were subsidies provided on loans. As this was beneficial to the members, the field officers did not discourage this practice. The field officers saw that the MFI and the SBLP served different needs and different borrowers. This type of bricolage 
follows the same logic of fitting each piece in (whether MFI or SBLP) wherever the need for this particular service is greatest.

Some basic differences between the SBLP and Grameen models are shown in Table 2.

Meso-level fit: varying program design

Over time, it was observed that, through a process of improvisation, policy actors modified the original design to better match local needs and practices. Unlike simple embedding and specification, improvisation modifies the essential template of the model.

\section{Changing forms of MFIs}

Over time, MFIs found that the need for loans by low-income groups were far in excess of the amount social entrepreneurs could raise personally and from banks. In order to access more funding and meet the needs of more individuals, many MFIs transformed their legal identity from those usually adopted by not-for-profits (such as trusts and societies) to more commercially oriented forms such as "non-banking finance companies". Sriram (2010) examined some of these transformations, which in some cases diluted the social objectives of some of the large MFIs in the country. The result of these developments was that there was a wide variety of actors all called "MFIs".

\section{Development of unique characteristics of the SBLP}

In the case of the SBLP, NABARD's emphasis was on financial services. NABARD's original circular was entitled "Improving access of rural poor to banking" (NABARD 1991). NGOs were viewed initially as merely conduits between banks and the people. However, the involvement of NGOs in the SBLP brought pressures to make the program

Table 2 Comparing SBLP and MFI (Grameen) models

\begin{tabular}{|c|c|}
\hline SBLP & MFI/Grameen \\
\hline Loan advanced by commercial bank & Loan advanced by MFI \\
\hline $\begin{array}{l}\text { Group members trained to do record keeping and } \\
\text { bank transactions }\end{array}$ & MFI staff do record keeping and bank transactions \\
\hline Loans are given to SHGs which on lend to members & $\begin{array}{l}\text { Loans are given to members individually though on } \\
\text { a joint liability basis }\end{array}$ \\
\hline Smaller loans, lower interest rates & Larger loans, higher interest rates \\
\hline Savings for $6-12$ months needs to precede borrowing & $\begin{array}{l}\text { Loans are given without any prior savings period. } \\
\text { In fact savings cannot be collected by MFIs due } \\
\text { to regulatory reasons }\end{array}$ \\
\hline $\begin{array}{l}\text { Delivery of microcredit viewed by some NGOs as } \\
\text { secondary to goals of female empowerment and } \\
\text { social transformation }\end{array}$ & Microcredit is the main focus \\
\hline $\begin{array}{l}\text { On an ad hoc basis, Government subsidies are given } \\
\text { to SHGs by way of grants equivalent to a part of the } \\
\text { loan }\end{array}$ & There is no subsidy element in MFIs \\
\hline $\begin{array}{l}\text { Broader social agenda, skills training, savings } \\
\text { program }\end{array}$ & $\begin{array}{l}\text { Uniformity of service, professional recordkeeping } \\
\text { practices }\end{array}$ \\
\hline Poor quality control across groups & Lacks savings programs \\
\hline
\end{tabular}


evolve beyond simply providing financial services. We describe a few concrete examples of this:

1. The NGOs brought to the program not just material resources such as trained workers but also their ethical framework, which emphasized empowerment and other social issues. In fact, some NGOs view delivery of microcredit as only secondary goal to the social aspects. For instance MYRADA, the NGO, which was closely involved in the early development of the SBLP, mentions on its web site that its objective is "to help the poor help themselves... by forming SHGs (Self-Help Groups) and through partnerships with other organizations". At another point, MYRADA mentions that it "has always been clear that it should not compromise its development role with the role of a financier" (www.myrada.org).

2. Because of the NGOs' focus on women's empowerment, capacity development became a central focus of the SBLP. This has been done through both formal training as well as informal interactions with NGO workers during group meetings. Often NGO workers advise the group on the proper conduct of group meetings, group decision making, and conflict resolution. The SHG becomes a training ground for women to take on more public roles and participate more actively in political processes. A study by EDA-APMAS (2006) of 214 SHGs in 108 villages in four states of India found that one in four SHGs had a woman member that ran for political office.

3. The SHGs also provide an umbrella group for mobilizing collective action in the village. EDA-APMAS (2006) found that $30 \%$ of the SHGs in the sample were involved in specific community actions. The community actions included efforts to improve community services (such as water supply, education, roads, health care, and veterinary care), stop alcohol sale, contribute finance and labor for new infrastructure projects, protect natural resources, and mobilize giving to charity.

4. The most important innovation of the SBLP was the development of SHG federations. These federations were formed by SHGs in a region coming together to facilitate exchange of ideas and derive greater capacity for collective action. SHG federations are an important example of how institutional models are shared by poor constituencies. These federations are formed at various levels: village, sub-district, and district. This structure results in a multiplier effect with regard to sharing of information and innovations from one SHG in a village to SHGs throughout the district. Their capacity for coordinated collective action is also considerable. The outreach of SHG federations has been used in health information campaigns, disaster relief activities, and women's rights advocacy. They have been even used to implement Government programs such as mid-day meal schemes in Government schools. Other SHG federations used their combined power to forge market linkages for their members by collective marketing or contracting with large buyers of products such as milk commonly sold by members. Essentially, these SGH federations became learning-and-action communities.

Once formed, SHG federations adopt objectives based on their member's needs. More than half of the 94,000 SHG federations have adopted financial objectives such as borrowing in bulk from banks and then on-lending to SHGs (Srinivasan 2009). In such cases, the SHG federation virtually acts like an MFI. SHG federations having non-financial objectives show a wide variety of objectives such as capacity development of member SHGs (e.g., providing training in book-keeping and auditing) and improvement of livelihood of members (e.g., collective marketing of market products such as milk). 
An interesting example of an SHG federation that successfully innovated a social welfare scheme is that of Kadamalai Federation in Theni District of Tamil Nadu. This federation, promoted by Dhan Foundation, has evolved a mutual health insurance program, fully owned and managed by the community. The model is based on the pooling of risk among SHG members and is backed up by reinsurance. Due to inadequate health care facilities in the area, the scheme has its own hospital for primary health care and has tied up with other hospitals for secondary health care. http://www.ilo.org/gimi/gess/RessShow Ressource.do?ressourceId=6191

5. The characteristics of SHGs are influenced by the particular NGO involved during its inception. Some NGOs take special initiatives to give the SHGs a sense of identity and unity. For instance, Bullock Cart Workers Development Association (BWDA), an NGO based in Tamil Nadu, provides uniforms to SHG members at reasonable prices which the members can wear during community activities. We interviewed S., an SHG member of BWDA, about this practice and she said "When we all wear our 'uniform' saris which BWDA has provided us at a reasonable cost, we have a strange sense of power. Everyone even on the street looks at us with respect."

6. NGOs also often developed initiatives that meet local needs unrelated to financial services. BWDA for instance noticed that their SHG members often heavily draw down their carefully built-up savings to buy items for festivals, as typically the prices of these goods go up at this time. It therefore initiated a scheme of itself buying these goods in bulk in advance of the festival and later distributing it at cost to SHG members. In the words of S., SHG member: "During every festival, BWDA provides the items required by us at reasonable prices. We find their care touching, almost like what a woman would expect from her parental home".

Both the SBLP and the MFI models have, over a period of time, developed their own strengths and weaknesses. The strengths of the SBLP include its wider social agenda, the training provided to group members, and its emphasis on savings. Its primary weakness is that as groups manage themselves after a point, there is wide variation in quality observed between groups (EDA-APMAS 2006).

Over time, new types of bricolage resulted in various hybrid organizational designs. Some NGOs started their own MFI programs by raising funds from Government agencies and financial institutions. While their programs continue to use the broad SBLP framework, instead of SHGs approaching banks for the loans, the loans were given by the NGOs themselves. However, the most interesting type of bricolage occurred at the local, household level as will be described in "Micro-level fit: household appropriation".

Micro-level fit: household appropriation

\section{Household strategies}

The third level or scale at which we found processes of fit involved the ways households appropriated or fitted in the microfinance programs into their own needs and routines, and vice versa. At this level, program officers have already made institutional and program design choices, and the only question is how the user takes advantage of the programs. The choices at this stage do not lie with the program managers but the individuals and household recipients.

For this section, we conducted interviews with twenty-three female members (i.e., loan recipients) of the GVMFL. Mainly, we were interested in how the members fit the program 
into their daily round and needs of their households. We recruited women with only a minimal set of criteria, namely that they were active recipients and had been so for at least 3 years. The 3 -year period is a common threshold employed in the literature to indicate microfinance members who had enough experience with the programs to be employing the loans effectively. The interviews used, as a framework, only a basic set of guide questions that the interviewer sometimes referred to, but these were essentially semi-structured and, in part, open-ended. The interviews were conducted in Tamil, and the interviewer recorded responses on paper during the interview. We also supplemented these with selected interviews with field officers of the GVMFL as a way to verify the insights from our conversations with the members.

It is interesting to consider that twelve of the twenty-three interviewees had, contrary to program practice, joined both MFI and SBLP programs. In response to questions on which model was superior, it was surprising to find that all these women viewed each model as serving different purposes. So, contrary to our expectations with regard to a competition between the two models, we found out that borrowers often took advantage of both programs because they made use of each type of program to meet different purposes. For example, 34-year-old Pr. who being a graduate was the most highly educated of our interviewees had this kind of dual membership. A salesperson in the local music shop, she has been an MFI member for 3 years and had availed loans to buy goats which she bred and later sold for a profit. She thought it important last year to also take a membership in an SHG due to the opportunities for taking up leadership roles. She was the "Deputy Leader" of her SHG and she was happy that she was learning new things such as keeping basic accounts. She was also looking forward to involving herself in community actions. C., a 31-year-old tailor, was a member in both an MFI and an SHG. She finds that both programs have their uses. She depends on the MFI for regular access to finance, whereas she is part of the SHG so that she is aware of community initiatives in the village and is in a position to take advantage of those that she finds useful.

The other women interviewed echoed similar sentiments. They viewed the two programs as being qualitatively different and used them in complementary fashion. While members used MFIs for access to resources, they turned to the SBLP not only for funds but for access to skills, experience in deciding on group priorities, developing tactical skills in pressing their agenda, and access to information on Government initiatives. The fact that the groups were linked to public sector banks offered them a distinct and respectable identity, giving them a sense of empowerment. The membership in the MFI on the other hand was seen as the key to a reliable and predictable source of funding. The women valued this membership as well and were dependent on it for working capital as well as to meet lump sum expenses. This process of mixing of the two distinct programs and matching with the unique needs of each household is bricolage. As regards the loans availed by the members form MFIs and SHGs, these were fitted in according to household needs at the time the loan was disbursed.

Table 3 provides the case study of P., a member of an MFI and an SHG, diagramming financial cash flows, which reveals how each loan was used.

In Table 3, we see the active process of bricolage as a fitting of multiple sources of loans into the household budget according to suitability, the latter determined in this case by criteria of loan amount and timing. In this case, the bricoleur keeps the raw materials separate and fits them wherever they are most useful. Contrary to the assumptions of the loan programs, members did not select one microfinance program or another-rather, they combined them in different ways, according to their individual characteristics. 
Table 3 Household profile

P., 27 years old, runs a tea shop along with her husband in Sembattur, a village in Pudukkottai district, Tamil Nadu, with a population of around 2,500. She lives with her husband and four children aged 11, 8,5 , and 2 years in a rented house near the shop. As her shop is on the main road and is one out of just three similar ones in the village, there is a stream of regular customers who patronize it. Another set of customers comprise drivers of vehicles passing through the village. Last year, the earnings from the tea shop fell substantially for a couple of months as due to repair on the road adjoining it, which reduced street and pedestrian traffic considerably. To supplement income, at times "P" and her husband lease out land for some agriculture activity, which, at the moment, is a break-even proposition

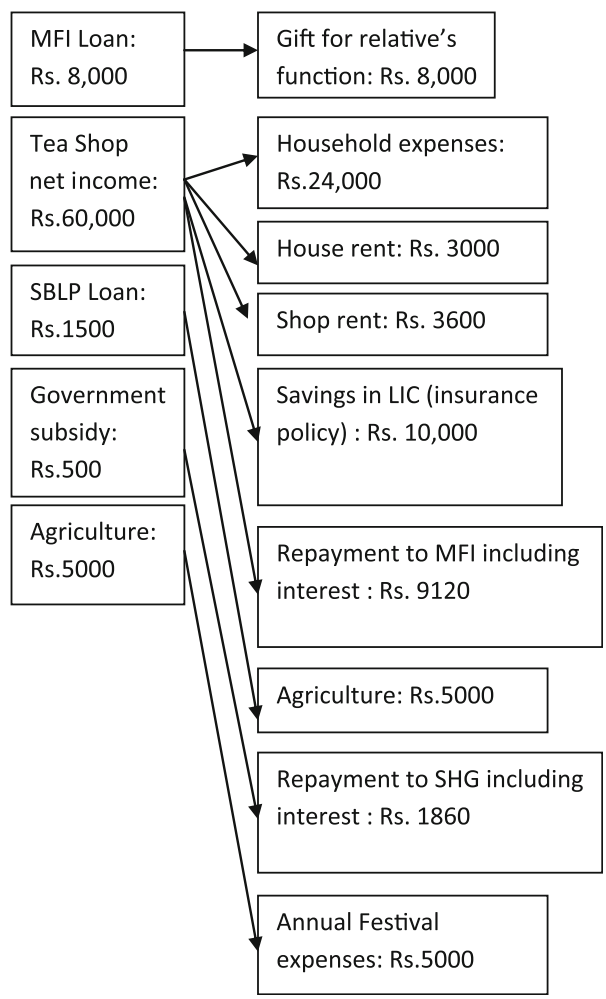

P. has been a member of a micro finance institution, Grama Vidiyal Micro Finance Limited (GVMFL) a micro finance institution which provides micro credit. She used her first loan of Rs. 5,000 to buy an electric grinder for the tea shop and her second loan of Rs. 7,000 to buy utensils and other things for the shop. This year she has got a loan of Rs. 8,000. She is also simultaneously, a member of a self-help group (SHG) for the last two years and this year she got a loan of Rs. 1,500 from there as well. The SHG also obtained a Government subsidy to the extent of Rs. 500 per member toward repayment of the loan

As shown in the chart, loans are fitted into the budget according to current household needs and depending on the value of the loan and the time of disbursement. This year, the MFI loan was of the right amount to purchase a gift for a relative on a special occasion. The SBLP loan was used for agriculture, as it happened that it was disbursed at the time when inputs for farming were to be purchased. Asked if she prefers the MFI or the SBLP, "P" smiles and says "they are both good, both of them help us"

Adaptation is evident-e.g., physically fitting the womens' daily routines to the programs. This is important, as our interviews with program staff indicates that one of the primary reasons for people dropping out of the programs is inability to attend meetings. In 
a sense, these women seemed to have fit both models into their schedules and budgets, so as to leverage the strengths of each model in an overall strategy. The household is an important site for bricolage.

\section{Double-talk}

The interviews with the women revealed yet another mode of local fit, which we did not expect. As we see in Table 3, the way the households utilized both sources of microfinancing ran counter to the formal program objectives as different microfinance programs were mixed and matched. In other cases, there were instances of loans being availed by women but being utilized for businesses run by their husbands. While the MFI and the SBLP target loans to women in order to encourage them to have their own source of income, some members used the loans to fund enterprises run entirely by their husbands. Surprisingly, they viewed the enterprises as their own, in keeping with Indian ethos and culture. They viewed it merely as an allocation of responsibilities among household members with regard to running the microenterprise and attending weekly microfinance group meetings, based on practical considerations (e.g., men often cannot attend these meetings as they leave for work early, while women cannot engage themselves in the enterprise due to other household responsibilities). They did not view it as contrary to MFI or SHG program objectives. In both examples above, we find local strategies that contradict the formal parameters of the microcredit programs.

How do both co-exist, meaning local narratives and the broader, formal narratives of the program? Simply, as two different narratives that do not encounter each other in a formal sense and, so, avoid explicit conflict between formal program goals and local household strategies. The women simply engage in double-talk, which is formally agreeing to overall program objectives, while employing alternative strategies locally. This is akin to what Argyris and Schön describe as formal program theories and more licit, theories-in-place, co-existing (Argyris and Schön 1974), and what Goffman refers to as the simultaneous existence of frontstage and backstage performance (Goffman 1959, 1990). Rather than frontstage versus backstage, perhaps a more appropriate dualism is that of formal versus informal. This is a form of institutional irony that we believe to be an important form of institutional coherence.

We summarize the schema for institutional fit in Table 4. We caution the reader, however, that such a list as found in the table is by no means exhaustive or definitive. Rather, they are just the most distinct modes of action found when examining microfinance in India close up.

\section{Conclusions}

We tried to illustrate how, by focusing closely upon how and why programs evolve over time, we find distinct mechanisms of making fit at work. We believe that the exercise of describing mechanisms of fit, in concept and in practice, to be an important research agenda. In the case studied herein, we found that such a focus helped us see the logic behind the sometimes bewildering array of variations in microfinance. These variations can often be traced to deliberate actions by policy actors to make their program more sustainable or more appealing to its particular set of beneficiaries, or to particular events and contingencies that occur over the life of the program. The logic is not one of optimality, but survival, appropriateness, and common sense-in other words, of fit. 
Table 4 Schema: Mechanisms for institutional fit

\begin{tabular}{l}
\hline Constructive processes \\
\hline Mimesis \\
Coercion \\
Normalization \\
\hline Ecological processes \\
\hline Specification \\
Adaptation \\
Improvisation \\
Bricolage \\
Double-talk
\end{tabular}

This type of research, which mainly involves observing policy actors as they improvise new practices in the field (or interviewing them ex post), also provides insights into the question of: how should a program be designed in the first place? Design, it seems, can evolve over time through a network of actors and their myriad actions. But evolution is not a pre-ordained process, and it requires actors that are empowered to act in a design capacity in the field. This suggests a need to fashion programs that allow and perhaps encourage such incremental modifications by local actors and street-level bureaucrats. Figure 1 is a helpful conceptual aid, in this regard. As is made plain in the figure, a program or policy can be understood as a coming together of text and context-i.e., of universal and particular elements. But the commingling of universal and particular can, in fact, be deliberately facilitated by program designers. Program designers can also provide guidance as to how local actors might go about making modifications.

On the other hand, our work also implies the danger of purely "textualist" policy-i.e., designs that exist as autopoeitic systems that are insulated from the particulars of context. These policies and programs can alienate local communities and actors, simply by their sheer autonomy.

The policy and organizational literature has long recognized the improvisational, evolutionary dimension of program design. However, a closer look at mechanisms of program evolution, as we have taken here, seems to us a contribution to the literature on policy transfer and program implementation as we encourage researchers to look further down the road in the life of a program and closely watch how program design continues to evolve.

Acknowledgments The authors express their appreciation for the comments and suggestions received from the editor and two anonymous reviewers, as well as an earlier review by Michael Howlett of Simon Fraser University.

Open Access This article is distributed under the terms of the Creative Commons Attribution License which permits any use, distribution, and reproduction in any medium, provided the original author(s) and the source are credited.

\section{References}

Aghion, B., \& Morduch, J. (2005). The economics of microfinance. Cambridge, MA: The MIT Press.

Argyris, C., \& Schön, D. A. (1974). Theory in practice: Increasing professional effectiveness. San Francisco, CA: Jossey-Bass. 
Bardach, E. (2004). Presidential address-Eugene Bardach. The extrapolation problem: How can we learn from the experience of others? Journal of Policy Analysis and Management, 23(2), 205-220.

Berkes, F. (2007). Community-based conservation in a globalized world. Proceedings of the National Academy of Sciences, 104(39), 15188-15193.

Berman, P. (1980). Thinking about programmed and adaptive implementation matching strategies to situations. In H. Ingram \& D. Mann (Eds.), Why policies succeed or fail. Beverly Hills, CA: Sage.

Bobrow, D. B., \& Dryzek, J. S. (1987). Policy analysis by design. Pittsburgh: U. Pittsburgh Press.

Chandler, A. (1962). Strategy and structure: Chapters in the history of American industrial enterprise. Cambridge, MA: MIT Press.

Derrida, J. (1978). Writing and difference (L'écriture et la Différence. A. Bass, Engl. trans.). Chicago: University of Chicago.

DiMaggio, P. J., \& Powell, W. W. (1983). The iron cage revisited: Institutional isomorphism and collective rationality in organizational fields. American Sociological Review, 48(2), 147-160.

Dolowitz, D., \& Marsh, D. (2000). Learning from abroad: The role of policy transfer in contemporary policymaking. Governance, 13(1), 5-24.

Donaldson, L. (1996). The normal science of structural contingency theory. Chapter 1.2. In S. Clegg, C. Hardy, \& W. Nord (Eds.), The handbook of organization studies. London: Sage.

Donaldson, L. (2001). The contingency theory of organizations. Thousand Oaks: Sage.

Douglas, M. (1986). How institutions think. Syracuse: Syracuse University Press.

EDA-APMAS (2006). Self help groups in India a study of the lights and shades.http://www.edarural. com/documents/SHG-Study/Executive-Summary.pdf. Accessed 2 Oct 2009.

Freeman, J. H., \& Audia, P. (2006). Community ecology and the sociology of organizations. Annual Review of Sociology, 32:145-169.

Gadamer, H. (1960). Truth and method (Trans. G. Barden, 1975). New York: Continuum.

Gibbons, D. S. (1999). International replications of Grameen banking: What can the poultry network learn from it? Paper presented at workshop on poultry as a tool in poverty eradication and promotion of gender equality, Denmark, March 22-26 http://www.fao.org/docrep/004/AC154E/AC154E00.htm. Accessed 2 Oct 2009.

Goffman, E. (1959). The presentation of self in everyday life (p. 1990). Edinburgh: University of Edinburgh, Social Sciences Research Centre, reprint Penguin Books.

Granovetter, M. (1985). Economic action and social structure: The problem of embeddedness. American Journal of Sociology, 91, 481-510.

Hannan, M., \& Freeman, J. (1977). The population ecology of organizations. American Journal of Sociology, 82, 929-964.

Harper, M. (2002). Self help groups and Grameen Bank groups : What are the differences? In T. Fisher, \& M. S. Sriram (Eds.), Beyond micro-credit putting development bank into micro-finance (pp 169-198). New Delhi: Vistaar Publications.

Howlett, M. (2009). Governance modes, policy regimes and operational plans: A multi-level nested model of policy instrument choice and policy design. Policy Sciences, 42, 73-89.

Howlett, M., \& Rayner, J. (2008). Third generation policy diffusion studies and the analysis of policy mixes: Two steps forward and one step back? Journal of Comparative Policy Analysis: Research and Practice., 10(4), 385-402.

Hull, C., \& Hjern, B. (1987). Helping small firms grow: An implementation approach. London: Croom Helm.

Ingram, H., \& Schneider, A. (1990). Improving implementation through framing smarter statutes. Journal of Public Policy., 10(1), 66-87.

Lawrence, P., \& Lorsch, J. (1967). Organization and environment: Managing differentiation and integration. Boston, MA: Division of Research Graduate School of Business Administration Harvard University.

Lejano, R. (2006). Frameworks for policy analysis: Merging text and context. New York: Routledge.

Lejano, R. (2008). The phenomenon of collective action: Modeling institutions as structures of care. Public Administration Review. May/June, 491-504.

Levi-Strauss, C. (1966). The savage mind. Chicago, IL: Univ. of Chicago.

Mandell, M., \& Steelman, T. (2003). Understanding what can be accomplished through interorganizational innovations: The importance of typologies, context and management strategies. Public Management Review., 5(2), 197-224.

March, J., \& Olsen, J. (1989). Rediscovering institutions: The organizational basis of politics. New York: Free Press.

Matland, R. E. (1995). Synthesizing the implementation literature: The ambiguity-conflict model of policy implementation. Journal of Public Administration Research and Theory, 5, 145-174. 
May, P. (1992). Policy learning and failure. Journal of Public Policy, 12(4), 331-354.

Mazmanian, D., \& Sabatier, P. (1989). Implementation and public policy (revised ed.). Latham, MD: University Press of America.

NABARD. (1991). Circular dated July 24, 1991, Accessed 2 Feb 2010 at http://www.nabard. org/fileupload/DataBank/Circulars/circ_rbi24071991.pdf.

Odum, E. (1960). Ecology. New York: Holt, Rinehart, and Winston.

Ostrom, E. (2008). The challenge of common-pool resources. Environment, 50(4), 8-21.

Powell, W., \& DiMaggio, P. (1991). The new institutionalism in organizational analysis. Chicago: University of Chicago Press.

Pressman, J., \& Wildavsky, A. (1979). Implementation: How great expectations in Washington are dashed in Oakland: Or, why it's amazing that Federal programs work at all, this being a saga of the Economic Development Administration as told by two sympathetic observers who seek to build morals on a foundation of ruined hopes. Berkeley: University of California Press.

Pugh, D. S. (1990). Organization theory: Selected readings (3rd ed.). Harmondsworth: Penguin Books.

Quinones Jr., B. R., \& Seibel, H. D. (2000). Social capital in microfinance: Case studies in the Philippines. Policy Sciences, 33, 421-433.

Rapley, J. (1996). Understanding development: Theory and practice in the third world. Boulder, CO: Lynne Rienner.

Ricoeur, P. (1991). From text to action: Essays in hermeneutics II. London: The Athlone Press.

Rose, R. (1991). What is lesson-drawing? Journal of Public Policy, 11, 3-30.

Rose, R. (2005). Learning from comparative public policy: A practical guide. Oxon: Routledge.

Sabatier, P. (2007). The need for better theories. In P. Sabatier (Ed.), Theories of the policy process (2nd ed.). Westview: Boulder, Col.

Sabatier, P. (2008). Top-down and bottom-up approaches to implementation research: A critical analysis and suggested synthesis. Journal of Public Policy, 6, 21-48.

Schneider, A., \& Ingram, H. (1997). Policy design for democracy. Lawrence: University of Kansas.

Scott, W. R. (1995). Institutions and organizations. Thousand Oaks, CA: Sage.

Scott, W. R. (2001). Institutions and organizations (2nd ed.). Thousand Oaks, CA: Sage.

Scott, W. R., \& Meyer, J. (1983). The organization of societal sectors. In J. Meyer \& R. Scott (Eds.), Organizational environments: Ritual and rationality. Beverly Hills: Sage.

Sewell, W. F. (1992). A theory of structure: Duality, agency, and transformation. The American Journal of Sociology, 98(1), 1-29.

Srinivasan, N. (2009). Microfinance India: State of the sector report 2008. New Delhi: Sage.

Sriram, M. S. (2010). Commercialisation of microfinance in India: A discussion on the emperor's apparel. IIM Ahmedabad Working Paper.

Stinchcombe, A. L. (1965). Organizations and social structure. In J. G. March (Ed.), Handbook of organizations. Rand McNally: Chicago, IL.

Strang, D., \& Soul, S. (1998). Diffusion in organizations and social movements: From hybrid corn to poison pills. Annual Review of Sociology, 24, 265-290.

Van Meter, D., \& Van Horn, C. (1975). The policy implementation process: A conceptual framework. Administration and Society, 6, 445-488.

Weatherley, R., \& Lipsky, M. (1977). Street-level bureaucrats and institutional innovation: Implementing special education reform. Harvard Educational Review, 47, 170-196.

Weick, K. E. (1988). Introductory essay: Improvisation as a mindset for organizational analysis. Organization Science, 9(5), 543-555.

Wright, G. (2000). Microfinance systems: Designing quality financial services for the poor. London: Zed Books and Dhaka: University Press. 